\title{
The first record of amphibians as paratenic hosts of Serpinema larvae (Nematoda; Camallanidae)
}

\author{
González, CE.* and Hamann, MI.* \\ Centro de Ecología Aplicada del Litoral, Consejo Nacional de Investigaciones Científicas y Técnicas \\ C.C. 291, CP 3400, Corrientes, Argentina \\ *e-mail: cynthyaelizabethg@hotmail.com, monika_hamann@yahoo.com \\ Received May 24, 2006 - Accepted July 17, 2006 - Distributed August 31, 2007
}

(With 4 figures)

Until now the third-stage larvae of Serpinema trispinosum (Leidy, 1852) was only found infecting aquatic snail and planktonophagous fish as paratenic hosts (Bartlett and Anderson, 1985; Moravec et al., 1998). The life cycle of this nematode is unknown. Apparently, the freshwater turtles may become infected by ingestion of zooplankton intermediate hosts (e.g., copepods) or by feeding on paratenic hosts (Moravec, 1998). Adults of S. trispinosum are common parasites of freshwater turtles from North and Central America (Baker, 1987; Moravec and Vargas-Vázquez, 1998).

Lysapsus limellum Cope, 1862 is a member of the frog family Hylidae. It is distributed exclusively in South America, in Uruguay, Paraguay, Bolivia and the north of Argentina (Frost, 2004). In Argentina, L. limellum is restricted to some areas adjacent to the Paraguay and Paraná rivers. It shows a great preference for aquatic habitats and occurs in permanent and semipermanent ponds.

Studies on the parasite fauna of L. limellum from Corrientes, Argentina showed the presence of thirty three nematode larvae of the family Camallanidae. Specimens were identified as third-stage of Serpinema cf. trispinosum.

Forty three amphibians were collected in a pond located $15 \mathrm{~km}$ from Corrientes City $\left(27^{\circ} 28^{\prime} \mathrm{S}\right.$ and $\left.58^{\circ} 50^{\prime} \mathrm{W}\right)$, province of Corrientes, Argentina between December, 2000 and January, 2001. They were captured with a $45 \mathrm{~cm}$ diameter dip net. Nematodes were recovered from the intestine, killed and fixed in hot water $\left(80^{\circ} \mathrm{C}\right)$, stored in $70^{\circ}$ ethyl alcohol and cleared in lactophenol for further examination. Drawings and measurements were made with the aid of a Zeiss microscope with a lucida camera. Measurements are given in micrometers $(\mu \mathrm{m})$ as the minimum-maximum, followed by the mean \pm standard deviation in parentheses.

Morphology (Figures 1-4)

Based on 11 specimens. Nematodes with colourless body and almost smooth cuticle, 1170.0-1930.0 (1666.0 \pm 226.0$)$ long by 46.0-80.0 (57.0 \pm 11.0$)$ wide. Cephalic end with 8 small papillae and lateral amphids. Buccal capsule is of the "Paracamallanus" type. Anterior portion $37.0-42.5(40.09 \pm 1.84)$ long by 25.3 - 43.0 (31.0 \pm 6.0$)$ wide, formed by two wide, lateral, valve-like structures with ribs at the inner side. This por-

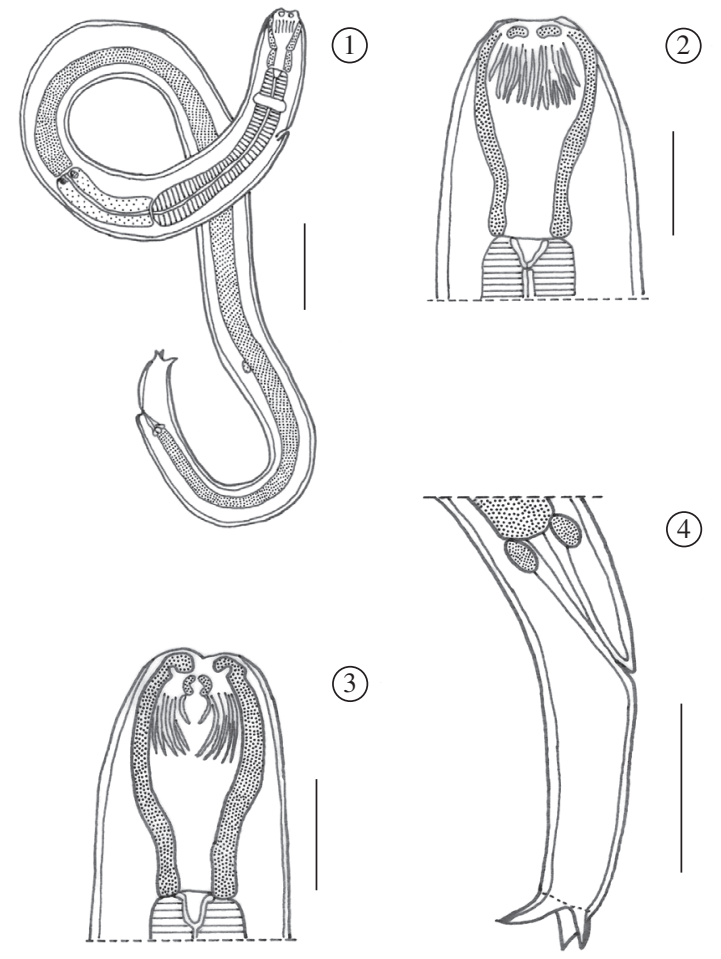

Figures 1-4. Serpinema cf. trispinosum collected from the intestine of Lysapsus limellum from Corrientes, Argentina. 1) Third-stage larva, general view; scale-bar: $200 \mu \mathrm{m}$. 2) Buccal capsule, lateral view; scale-bar: $30 \mu \mathrm{m}$. 3) Buccal capsule, dorsoventral view; scale-bar: $30 \mu \mathrm{m}$. and 4) Tail; scale-bar: $50 \mu \mathrm{m}$.

tion of capsule has 15 narrow, long, longitudinal ridges extending approximately along anterior two thirds of this portion, and 2-4 short ridges. Posterior portion of the buccal capsule is narrower, 16.0-22.0 (20.0 \pm 1.70$)$ long by $13.8-29.0(20.0 \pm 4.0)$ wide. This portion opens into the esophagus through a large funnel with sclerotized walls. The esophagus consists of two portions: muscular esophagus 197.8 - $305.0(227.0 \pm 31.0)$ long by $25.3-40.0(29.0 \pm 4.0)$ wide and glandular esophagus 184.0 - 275.0 (201.0 \pm 27.0$)$ long by $25.3-40.0$ (32.0 \pm $4.0)$ wide. Two large cellular nuclei present close to the 
posterior end of the glandular oesophagus. The nerve ring and excretory pore are 85.1-135.0 (106.0 \pm 13.0) and $126.5-158.7(142.0 \pm 12.0)$, respectively, from the anterior extremity. The small oval genital primordium is located in the posterior half of the body. The rectum is surrounded by numerous, big, glandular, rectal cells. Tail conical, 52.9 - $115.0(73.0 \pm 18.0)$ long, with three terminal cuticular spikes; length of dorsal spike 11.0 - 15.0 $(12.68 \pm 1.23)$; length of ventrolateral spikes 9.0-12.0 (10.36 \pm 0.89$)$.

The morphometrical data of the present specimens conform closely to Moravec et al. (1998) descriptions. These authors collected S. trispinosum from Cichlasoma urophthalmus (Günter) (Cichlidae, Perciformes) from the Yucatán Peninsula, Southeastern Mexico. Bartlett and Anderson (1985) founded third-stage larvae of S. trispinosum from naturally infected aquatic snails, Lymnaea stagnalis (L.) from Canada. The present report represents the first record of Serpinema larvae in amphibians, and suggests the importance of amphibians as paratenic hosts of freshwater turtle parasites. The genus Serpinema Yeh, 1960 is registered for the first time in Argentina.

Site of infection: intestine.

Locality: Corrientes City ( $27^{\circ} 28^{\prime} \mathrm{S}$ and $\left.58^{\circ} 50^{\prime} \mathrm{W}\right)$, province of Corrientes, Argentina.

Prevalence and intensity of infection: $16 \%, 4.7 \pm$ 4.0, 1-13.
Specimens deposited: Helminthological Collection of Centro de Ecología Aplicada del Litoral CECOAL 00112909 , CECOAL 00122104, CECOAL 01013101.

\section{References}

BAKER, MR., 1987. Synopsis of the nematoda parasitic in amphibians and reptiles. Canada: Memorial University of Newfoundland. Ocasional Papers in Biology, Department of Zoology, University of Guelph.

BARTLETT, CM. and RC. ANDERSON, 1985. Larval nematodes (Ascaridida and Spirurida) in the aquatic snail, Lymnaea stagnalis. Journal of Invertebrate Pathology, Sept. 1985, vol. 46, no. 2, p. 153-159.

FROST, DR. Amphibian Species of the World: an Online Reference. Version 3.0 (22 August, 2004) Electronic Database accessible at http://research.amnh.org/herpetology/amphibia/ index.html. [Accessed 28/04/06].

MORAVEC, F., 1998. Nematodes of freshwater fishes of the Neotropical Region. Czech Republic: Academia Praha.

MORAVEC, F. and J. VARGAS-VÁZQUEZ., 1998. Some endohelminths from the freshwater turtle Trachemys scripta from Yucatán, México. Journal of Natural History, Mar. 1998, vol. 32, no. 3, p. 455-468.

MORAVEC, F., MENDOZA-FRANCO, E. and VIVAS-RODRÍGUEZ., C. 1998. Fish as paratenic hosts of Serpinema trispinosum (Leidy, 1852) (Nematoda: Camallanidae). Journal of Parasitology, Apr. 1998, vol. 84, no. 2 , p. $454-456$. 